\title{
STUDY ON THE EFFECT OF RUBBER SOLE ON PRESSURE CHANGE OF FOOT MOVEMENT
}

\author{
Hao LIN ${ }^{1 *}$, Zhiying JIANG ${ }^{2}$ \\ ${ }^{1}$ Department of Sports, Sanjiang University, Nanjing, Jiangsu, 211101, China
}

${ }^{2}$ Department of Physical Education, Nanjing Communications Institute of Technology, Nanjing, Jiangsu, 210012, China

Received: 14.09.2017

Accepted: 15.01 .2018

https://doi.org/10.24264/Ifj.18.1.4

\section{STUDY ON THE EFFECT OF RUBBER SOLE ON PRESSURE CHANGE OF FOOT MOVEMENT}

ABSTRACT. With the progress of the times, more and more people are participating in sports to keep fit, which increased the demand and requirement on sport shoes, especially on their protection performance and shock absorption performance. The material and distribution of the rubber sole of sneakers often determine their quality and performance. This paper aims to analyze the performance of rubber sole and the pressure change of foot movement so as to provide reference for the design of sports shoes with excellent shock absorbing performance. KEY WORDS: rubber sole, foot movement, pressure, change

STUDIU PRIVIND INFLUENȚA TĂLPILOR DIN CAUCIUC ASUPRA MODIFICĂRII PRESIUNII LA MIȘCAREA PICIORULUI

REZUMAT. Odată cu trecerea timpului, tot mai mulți oameni fac sport pentru a se menține în formă, ceea ce a dus la creșterea cererii de încălțăminte sport, precum și la exigența cerințelor, în special în ceea ce privește gradul de protecție conferit și capacitatea de absorbție a șocurilor. Materialul și distribuția tălpilor de cauciuc al încălțămintei sport determină adesea calitatea și performanța acesteia. Lucrarea urmărește să analizeze performanța tălpilor din cauciuc și modificarea presiunii la mișcarea piciorului astfel încât să ofere o referință pentru proiectarea încălțămintei sport cu performanțe excelente în absorbția șocurilor.

CUVINTE CHEIE: talpă din cauciuc, mișcarea piciorului, presiune, modificare

ÉTUDE SUR L'EFFET DE LA SEMELLE EN CAOUTCHOUC SUR LE CHANGEMENT DE PRESSION AU MOUVEMENT DU PIED

RÉSUMÉ. Au fil du temps, de plus en plus de personnes font du sport pour rester en forme, ce qui a entraîné une demande accrue de chaussures de sport et des exigences élevées, notamment en ce qui concerne le degré de protection et la capacité d'absorption des chocs. Le matériau et la distribution des semelles en caoutchouc déterminent souvent la qualité et la performance des chaussures. Cet article vise à analyser la performance des semelles en caoutchouc et le changement de la pression au mouvement du pied afin de fournir une référence pour la conception de la chaussure sport avec une excellente performance d'absorption des chocs.

MOTS CLÉS: semelle en caoutchouc, mouvement du pied, pression, changement

"Correspondence to: Hao LIN, Department of Sports, Sanjiang University, No. 10 Longxi Road, Tiexin Bridge, Yuhua District, Nanjing, Jiangsu, 211101, China; E-mail: lin_hao76@yahoo.com 


\section{INTRODUCTION}

With the progress of science and technology, shoe-making technology has been greatly improved and people have put more emphasis on the performance of sports shoes. How to design sports shoes which can improve foot movement efficiency has become one of the key points in the research of the sports shoe manufacturing industry. By analyzing the foot pressure characteristics of the athletes in the walking race, Chinese scholar K.K. Wang found that functional insoles could reduce the risk of injury [1]. Chinese scholar W.J. Fu et al. discovered that there was little difference between the tibial acceleration peak value and the maximum pressure distribution in cement and grassland [2]. By measuring the pressure distribution and slippage of the shoe sole, Y. Yoshioka et al. [3] revealed the behavior of the sole during walking. Foreign scholar F.T. Tang et al. concluded that TCIFMP insoles were an effective corrective device that could be used for hind limb motion control, plantar stress relief and redistribution of elastic flat foot patients [4]. In this paper, sports foot sole pressure tests were carried out on both EVA rubber material soles and latex rubber material soles. By analyzing the stress condition of the two materials, the cushioning effect of the rubber soles was proved, which provided reference for the design of rubber sole shoes.

\section{Rubber Material for Shoes}

As China's natural rubber yield is small, synthetic rubber raw material [5] is often used to produce shoes, which has developed rapidly in recent years, with high level and large production scale. The successful application of synthetic rubber in the footwear industry makes up for the problem of China's lack of natural rubber production and broadens the application of rubber footwear. Synthetic resins including polystyrene (HS), ethylene/vinyl acetate (EVA) and thermoplastic elastomer (SBS) have also been widely used in rubber shoes [6], which further improved the performance and process adaptability of rubber shoes. Table 1 shows the applications and functions of synthetic rubber and resin main material.

Table 1: Applications and functions of synthetic rubber and resin main material

\begin{tabular}{|c|c|c|c|}
\hline Material category & Material name & Application & Function \\
\hline \multirow{4}{*}{ Synthetic rubber } & SBR latex & Used with natural latex & $\begin{array}{l}\text { Improve the stickiness of uppers } \\
\text { of shoes }\end{array}$ \\
\hline & Isoprene rubber & $\begin{array}{l}\text { Used for the production of } \\
\text { transparent soles }\end{array}$ & $\begin{array}{c}\text { Match with high-end fashion } \\
\text { shoes }\end{array}$ \\
\hline & Methylpolybutadiene & $\begin{array}{l}\text { With good slip resistance } \\
\text { performance, suitable for use in rain } \\
\text { shoes. }\end{array}$ & $\begin{array}{l}\text { Improve the skid resistance } \\
\text { performance }\end{array}$ \\
\hline & High styrene & $\begin{array}{c}\text { Used in the glue or latex of rubber } \\
\text { shoes }\end{array}$ & $\begin{array}{l}\text { Used in primer or mortar, to } \\
\text { improve the stickiness of shoes }\end{array}$ \\
\hline Synthetic resin & EVA & Largely used in midsoles & $\begin{array}{l}\text { Used as the outsoles of rubber } \\
\text { sandals and USB sports shoes }\end{array}$ \\
\hline
\end{tabular}

As rubber materials are increasingly applied in the shoemaking industry, the requirements on the performance of rubber materials are becoming more and more specific. The new development direction of rubber materials covers the following aspects: firstly, the weight of rubber materials should be reduced to make shoes lighter. The human engineering study [7] showed that every 1 gram increase in shoe weight can result in 6 gram load on the human foot. Secondly, the density of rubber materials should be decreased to lower the material hardness and increase flexibility so that shoe soles can better stand the bending force during movement and breakage can be avoided [8]. Thirdly, the rubber materials should have high plasticity, stretchability and abrasion resistance performance. Fourthly, the rubber materials should have artistic, anti-bacterial and durable characteristics. In the future, the shoemaking industry will have higher requirements on the performance of rubber materials [9]. Besides, composite rubber and related ancillary additive research will be accelerated. 


\section{MATERIALS - PREPARATION OF RUBBER MATERIAL SOLES}

\section{Main Raw Materials}

Raw material 1: natural rubber (NR), ethylenevinyl acetate copolymer (EVA) (with $18 \%$ of VA content), tetramethylthiuram disulfide (accelerator), bis-benzenesulfide (blowing agent).

Raw material 2: natural rubber (NR), styrene-butadiene rubber (SBR), stearic acid, sulfur monobenzenesulfide.

\section{The Main Equipment}

The main equipment is as follows: tworoll mixer, curing device, open mill [10], flat vulcanizing machine.

\section{Preparation Process}

\section{Preparation of EVA - Rubber Foam Materials}

Firstly, thin-passing was performed six times on natural rubber and ethylene-vinyl acetate copolymer. Then, white carbon black was added for plastication and mixing, followed by the addition of tetramethylthiuram disulfide. After the mixing, zipper pulls and cutting were performed on an open mill and then moulding foaming was carried out on a flat vulcanizing apparatus [11] to obtain the final EVA-rubber foam materials.

\section{Preparation of High Wear-Resistant Foam Rubber Materials}

First of all, a certain proportion of natural rubber (NR), styrene-butadiene rubber (SBR), stearic acid, foaming agent and abrasion agent were selected. After the natural rubber was plasticated, it was mixed with butadiene styrene rubber to form the sizing material, which was then batched off and placed at room temperature for 24 hours. After the above steps, the sizing material was added into an internal mixer, added with stearic acid and urea. After the machine was rechecked, the sizing material was discharged and placed in the open mill for hot refining so as to be processed into the shape of the sports soles. Then, after natural cooling, rough selvedge was cut to obtain the high wearresistant foam rubber materials.

\section{METHODS - FOOT PRESSURE TEST ON THE RUBBER SHOES}

\section{Research Objects}

In this study, ten male college students were selected as subjects, with the BMI index between the normal male range of 20-25 (age: 23 years old; height: $173-178 \mathrm{~cm}$; weight: $68-73$ $\mathrm{kg})$. The inclusion criteria for the subjects are as follows: love sports, with no foot deformity or injuries. Besides, the subjects kept good body conditions within 24 hours before the test to ensure the normal activity of the foot joints.

\section{Test Equipment}

Table 2 shows the test equipment applied in this study.

Table 2: Test equipment

\begin{tabular}{cc}
\hline Equipment & Function \\
\hline $\begin{array}{c}\text { Foot gauge (Deji Shoe Material Company) } \\
\text { Thickness gauge (Hongmao Instrument } \\
\text { Equipment Co., Ltd.) } \\
\text { Hardmeter (Shanghai Caichen Precision } \\
\text { Instrument Co., Ltd.) }\end{array}$ & $\begin{array}{c}\text { To measure the foot size of the subjects and set the size of the test } \\
\text { shoes to be } 42 \text { yards } \\
\text { Flat-plate pressure test instrument } \\
\text { (Beijing Dimei de'er Technology Co., Ltd.) } \\
\text { Insole type foot pressure tester } \\
\text { (Shenzhen Yijie Instrument Co., Ltd.) }\end{array}$ \\
\hline
\end{tabular}


Four pairs of test shoes $E, F, G$, and $H$ were made by a shoe factory, with soft soles made of EVA foam rubber material [12], hard soles made of EVA foam rubber material, soft soles made of high wear-resistant foam rubber material and hard soles made of high wear-resistant foam rubber material [13] respectively, which were similar in sole and upper structure and weight, thereby ensuring the accuracy of the test.

\section{Foot Pressure Test}

The test was completed in the Sports Biomechanics Laboratory, whose ground was decorated with tiles, which avoided the influence of ground deformation changes. Meanwhile, the lab temperature was controlled between 20$24^{\circ} \mathrm{C}$, with the humidity kept at $20 \%-40 \%$. Firstly the 10 subjects did warm up exercises before wearing the test equipment. After they wore the shoes, they walked, jogged and jumped with a constant speed. The walking speed was controlled at around $1 \mathrm{~m} / \mathrm{s}$ while the jogging speed was kept around $1.5 \mathrm{~m} / \mathrm{s}$ to ensure the validity of the experimental data. In addition, the height of the stool in the jumping test was unified to be $45 \mathrm{~cm}$.

\section{Purpose}

In this study, the insole type foot pressure distribution measurement system was applied to measure the foot pressure of the subjects during walking, jogging and jumping. By comparing the parameters such as peak pressure and pressuretime product values, the cushioning effects of different rubber materials were compared.

\section{Requirements}

The subjects chose the 41 yard insoles and did some adaptive training before the test [14] while the test system was calibrated. After replacing the test shoes, the measurement system was cleared in time to ensure the accuracy of the data. Besides, the position of the insole in the sports shoe was fixed to avoid errors caused by insole sliding.

\section{RESULTS AND DISCUSSION}

With the insole type foot pressure distribution measurement system, the foot pressure peak values of the subjects during the three motion tests under bare feet conditions and wearing the test shoes were measured. By analyzing the average pressure of the left and right foot under the standing state, it was concluded that the pressure of the left foot was smaller than that of the right foot. Therefore, the data of the right foot was taken as the experimental data.

\section{Analysis of Plantar Pressure}

whole foot peak values of experimental shoes and bare feet in movement

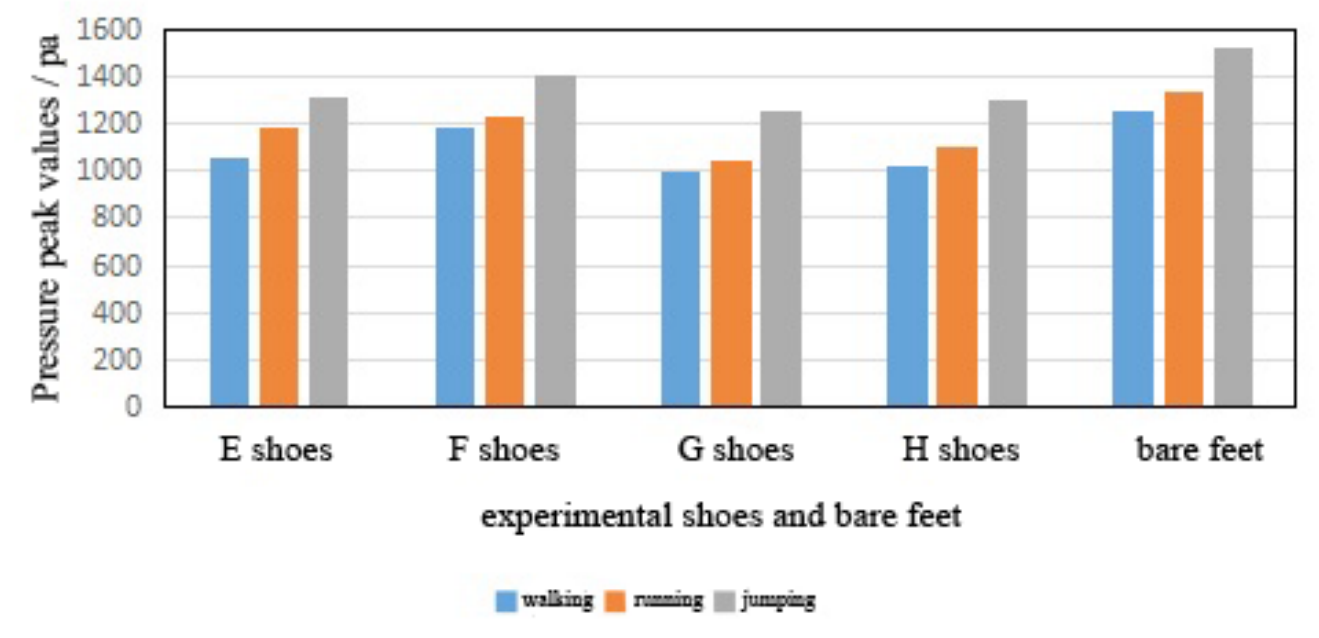

Figure 1. Whole foot peak values of experimental shoes and bare feet in movement 
As shown in figure 1, the pressure peak values wearing the test shoes were smaller than those in bare feet conditions, suggesting that the test shoes reduced the pressure on the subjects to some extent, playing a cushioning effect. The comprehensive foot pressure values of the four pairs of test shoes in walking, jogging and jumping were ranked as $\mathrm{F}>\mathrm{E}>\mathrm{H}>\mathrm{G}$. Suppose that the stress was the same, then smaller pressure peak values suggested greater action areas, i.e., the compactness between the feet and the shoes was high and stress distribution was dispersed, from which the cushioning effect of the shoes could be judged to be good. The ranking of the cushioning effect of the four pairs of test shoes was as follows: $\mathrm{G}>\mathrm{H}>\mathrm{E}>\mathrm{F}$.

\section{Foot Pressure • Time Product Analysis}

Figure 2 shows the product values of foot pressure peak values and time of the four pairs of test shoes during the three movements, which were calculated according to the following equation:

Product value $=$ pressure $\bullet$ time $=\frac{F}{S}$

(F: pressure; t: time; S: force area)

The product values could reflect the size of the subject's work wearing the test shoes during movements, which were ranked as $\mathrm{F}>\mathrm{E}>\mathrm{H}>\mathrm{G}$, suggesting that $G$ shoes were most helpful to the subjects, which improved the movement efficiency of the subjects, followed by $E$ shoes and $\mathrm{H}$ shoes, while $\mathrm{F}$ shoes could cause injuries to the feet of the subjects.

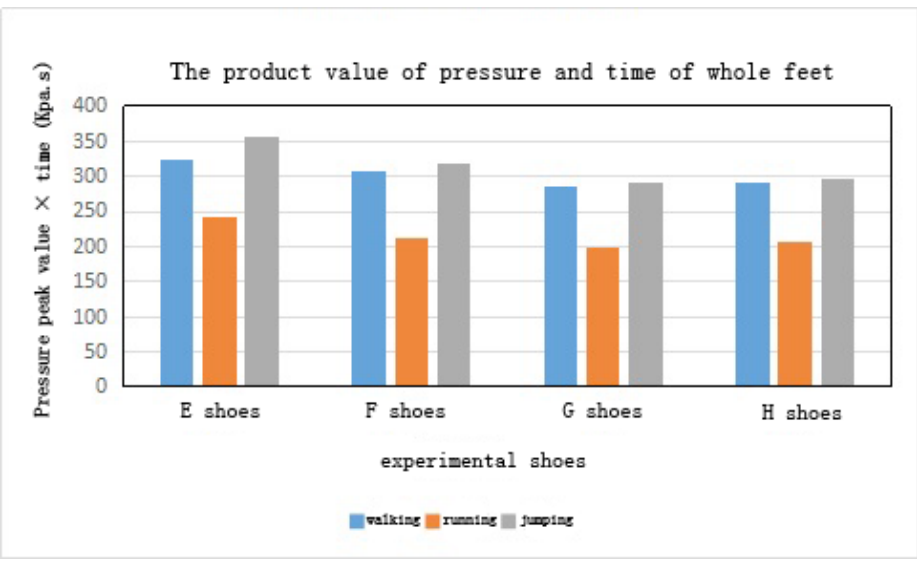

Figure 2. Product values of foot pressure peak values and time of the four pairs of test shoes during the three movements

\section{Analysis of the Trajectory of the Sole Pressure Centre}

While measuring the pressure peak values, the foot pressure measuring system also formed the foot pressure centre trajectory line, whose bending degree and length reflected the evenness of the force and the time of contact so as to reflect the stability of the shoe soles. As shown in figure $3, \mathrm{~F}$ shoes' pressure centre trajectory was the most bending and the shortest; the centre trajectories of $\mathrm{G}$ and $\mathrm{H}$ shoes were straight and long. Therefore, the stability ranking was as follows: $\mathrm{G}>\mathrm{H}>\mathrm{E}>\mathrm{F}$.

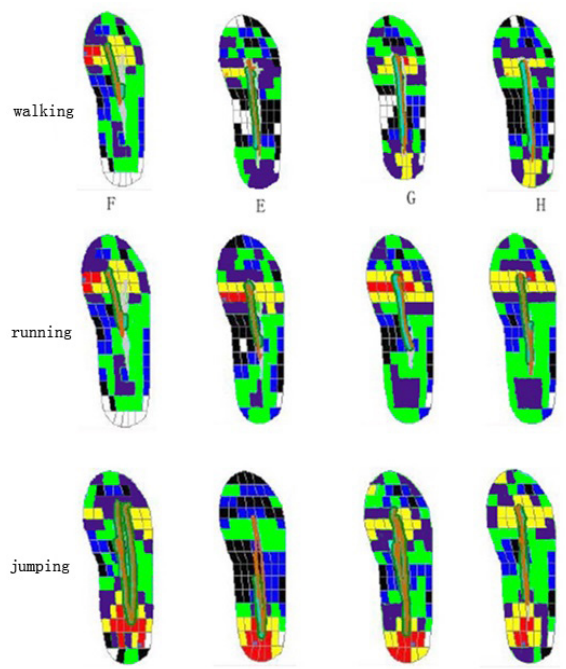

Figure 3. Test shoe foot pressure distribution centre trajectory line 


\section{CONCLUSION}

Compared with EVA foam rubber soles, high wear-resistant foam rubber soles had more excellent performance and better cushioning effects, which were lighter and more flexible, with smaller density. Soft rubber was more suitable as a material for sports shoe soles because it had a good stretch capacity and could prevent the subjects from injuries during movement. In conclusion, rubber soles could ease the foot pressure to certain extent and the use of rubber material to produce sports soles was an appropriate choice. Nevertheless, since sole structure design, upper design and colour design are all important factors to improve the quality of sports shoes, they need to be further studied in the future.

\section{REFERENCES}

1. Wang, K.K., Wang, Y.L., Guo, X., Song, Q.P., Zhang, C., Effect of Functional Insoles to Plantar Pressure Distribution of Race Walkers, Shandong Sports Science \& Technology, 2015, 2, 80-83.

2. Fu, W.J., Liu, Y., Li, L., Zhao, G.Y., The Effect of Sports Surface on Tibia Impact and Characteristics of Plantar Pressure in Jogging, Journal of Shanghai Physical Education Institute, 2013, 5, 89-94.

3. Yoshioka, Y., Iwai, T., Shoukaku, Y., Measurement of Pressure Distribution of Shoe Sole During Walking and its Relation to Slippage, ASME/STLE International Joint Tribology Conference, 2011, 47-49, https:// doi.org/10.1115/IJTC2011-61238.

4. Tang, F.T., Chen, C.H., Wu, C.K., Hong, W.H., Chen, K.J., The effects of total contact insole with forefoot medial posting on rearfoot movement and foot pressure distributions in patients with flexible flatfoot, Clin Neurol Neurosurg, 2015, 129, S8-S11, https://doi. org/10.1016/S0303-8467(15)30004-4.

5. Chen, J., Three Chinese State-owned Rubber Machinery Enterprises to Seek New Development by Integration, China Rubber, 2011, 12, 31.

6. Gregorova, V., Uncik, S., Characterization of Lightweight Concrete Produced from Plastics Waste - Polystyrene and EVA, Appl Mech Mater, 2017, 861, 24-31, https:// doi.org/10.4028/www.scientific.net/ AMM.861.24.

7. Buckle, P., The Perfect is the Enemy of the Good - Ergonomics Research and Practice.
Institute of Ergonomics and Human Factors Annual Lecture 2010, Ergonomics, 2011, 54, 1, 1-11, https://doi.org/10.1080/00140139.2 010.542251.

8. Boulogne, F., Giorgiuttidauphiné, F., Pauchard, L., How to Reduce the Crack Density in Drying Colloidal Material?, Oil \& Gas Science \& Technology, 2013, 69, 3, 397-404, https://doi. org/10.2516/ogst/2013119.

9. Khang, D.Y., Jiang, H., Huang, Y., Rogers, J.A., A Stretchable Form Of Single-Crystal Silicon For High-Performance Electronics On Rubber Substrates, Science, 2015, 311, 5758, 208, https://doi.org/10.1126/science.1121401.

10. Guo, L., Wang, C.S., Liu, Q.K., Su, D.J., NewType Vacuumizing Flat Vulcanizing Machine Structure Design and Experimental Research, Key Engineering Materials, 2013, 561, 218-222.

11. Rathnayake, W.G.I.U., Ismail, H., Baharin, A., Bandara, I.M.C.C.D., Rajapakse, S., Enhancement of the Antibacterial Activity of Natural Rubber Latex Foam by the Incorporation of Zinc Oxide Nanoparticles, J Appl Polym Sci, 2014, 131, 1, 1-15, https:// doi.org/10.1002/app.39601.

12. Julyanon, J., Kaesaman, A., Sakai, T., Lopattananon, N., Improvement of Structure and Properties of Nanocomposite Foams Based on Ethylene-Vinyl Acetate (EVA)/ Natural Rubber (NR)/Nanoclay: Effect of NR Addition, Key Engineering Materials, 2015, 659, 418-422, https://doi.org/10.4028/www. scientific.net/KEM.659.418.

13. Salgueiro, W., Somoza, A., Silva, L., Consolati, G., Quasso, F., Temperature Dependence on Free Volume in Cured Natural Rubber and styrene-butadiene rubber blends, Phys Rev E Stat Nonlin Soft Matter Phys, 2011, 83, 5 Pt 1, 051805, https://doi.org/10.1103/ PhysRevE.83.051805.

14. Lipfert, S.W., Günther, M., Renjewski, D., Grimmer, S., Seyfarth, A., A model-experiment comparison of system dynamics for human walking and running, J Theor Biol, 2012, 292, 292, 11-17, https://doi.org/10.1016/j. jtbi.2011.09.021.

(C) 2018 by the author(s). Published by INCDTPICPI, Bucharest, RO. This is an open access article distributed under the terms and conditions of the Creative Commons Attribution license (http:// creativecommons.org/licenses/by/4.0/). 